\title{
Growth limitation due to high pH and low inorganic carbon concentrations in temperate species of the dinoflagellate genus Ceratium
}

\author{
L. M. Søderberg, P. J. Hansen* \\ Marine Biological Laboratory, University of Copenhagen, Strandpromenaden 5, 3000 Helsingør, Denmark
}

\begin{abstract}
The effects of high pH and low DIC (dissolved inorganic carbon) concentrations on growth rates of the dinoflagellate Ceratium were studied using 2 different approaches: (1) $\mathrm{pH}$ drift experiments, in which both $\mathrm{pH}$ and DIC change during the experiment, and (2) constant $\mathrm{pH}$ and DIC experiments at a range of fixed $\mathrm{pH}$ and DIC levels. The upper $\mathrm{pH}$ limits for growth were between 8.7 and 9.1 for the 3 species tested (C. furca, C. tripos and C. fusus) and thus within an environmentally relevant $\mathrm{pH}$ range. Hence, for Ceratium spp. and other dinoflagellates with upper $\mathrm{pH}$ tolerances for growth below or around 9, high $\mathrm{pH}$ will most likely periodically be a limiting factor in coastal areas. Different upper $\mathrm{pH}$ limits for growth were found using either the $\mathrm{pH}$ drift or the constant $\mathrm{pH}$ methods for the larger Ceratium species, but, for the smaller species, the 2 methods provided similar results. The results therefore suggest a combined pH/DIC limitation for large species such as C. tripos and C. furca in natural waters.
\end{abstract}

KEY WORDS: pH · Inorganic carbon $\cdot$ DIC $\cdot$ Ceratium $\cdot$ Phytoplankton

Resale or republication not permitted without written consent of the publisher

\section{INTRODUCTION}

Seawater possesses a high buffer capacity (compared to most freshwater habitats) due to large amounts of dissolved inorganic carbon (DIC). This has previously led to the general belief that the $\mathrm{pH}$ of seawater is stable around $\mathrm{pH}$ 8.2. Recent research, however, has shown that the $\mathrm{pH}$ may rise to values $>9.5$ in nutrientenriched fjords and lagoons due to photosynthetic $\mathrm{CO}_{2}$ uptake by phytoplankton (Macedo et al. 2001, Hansen 2002). During algal blooms, when algal $\mathrm{CO}_{2}$ uptake from the water is larger than $\mathrm{CO}_{2}$ replacement from the atmosphere, the $\mathrm{pH}$ increases and the carbon equilibrium moves towards $\mathrm{CO}_{3}{ }^{2-}: \mathrm{CO}_{2} \leftrightarrow \mathrm{HCO}_{3}{ }^{-} \leftrightarrow \mathrm{CO}_{3}{ }^{2-}$ (Chen \& Durbin 1994). In oceanic waters, the amount of DIC is usually around $2 \mathrm{mM}$, and, at atmospheric equilibrium ( $\mathrm{pH} \mathrm{8.2),} \mathrm{the} \mathrm{majority} \mathrm{of} \mathrm{this} \mathrm{is} \mathrm{in} \mathrm{the} \mathrm{form} \mathrm{of}$ $\mathrm{HCO}_{3}^{-}$(approximately $90 \%$ ), whereas $\mathrm{CO}_{2}$ comprises $<1 \%$ and $\mathrm{CO}_{3}{ }^{2-}$ ca. $9 \%$ (Riebesell 2004).

Effects of high $\mathrm{pH}$ on algal growth can be either direct or indirect. High $\mathrm{pH}$ could, for example, directly affect the efficiency of proton pumps in the cell wall. Indirect effects of high $\mathrm{pH}$ could, for example, occur in the form of inorganic carbon limitation. Inorganic carbon limitation can occur if the algae are unable to utilise or have a low affinity for $\mathrm{HCO}_{3}^{-}$. Inside the cell it is necessary to convert $\mathrm{HCO}_{3}{ }^{-}$to $\mathrm{CO}_{2}$, since the sole substrate for carbon fixation by the primary carboxylating enzyme ribulose-1,5-bisphosphate carboxylase/oxygenase (Rubisco) is $\mathrm{CO}_{2}$. The interconversion of $\mathrm{CO}_{2}$ and $\mathrm{HCO}_{3}{ }^{-}$is catalysed by internal carbon anhydrase (CA). External CA can also be employed in the conversion of $\mathrm{HCO}_{3}^{-}$to $\mathrm{CO}_{2}$ outside the cell and subsequent $\mathrm{CO}_{2}$ uptake (Badger 2003). Whether all marine phytoplankton are able to utilise both $\mathrm{HCO}_{3}{ }^{-}$and $\mathrm{CO}_{2}$ and whether uptake of bicarbonate is a more energy-demanding process than $\mathrm{CO}_{2}$ uptake are topical issues (Burkhardt et al. 2001, Bartual \& Gálvez 2002, Riebesell 2004). If marine phytoplankton is $\mathrm{CO}_{2}$ limited, it implies that an increase in atmospheric $\mathrm{CO}_{2}$ would promote phytoplankton productivity (Hein \& Sand-Jensen 1997, Schippers et al. 2004) and perhaps increase the frequency or magnitude of blooms. 
Dinoflagellates belonging to the genus Ceratium are common in temperate waters, especially in the late summer and fall (Smetacek 1981, Jansen et al. 2006). In Scandinavian coastal waters, Ceratium spp. can comprise up to $90 \%$ of the protist biomass, and these species are thus of great ecological importance (Hansen \& Larsen 1992). Recent experiments have shown that some Ceratium species like C. furca and C. tripos are very sensitive to high pH (Schmidt \& Hansen 2001), with upper pH limits for growth as low as 8.3 to 8.4. Thus, we were puzzled as to how algae with such low $\mathrm{pH}$ limits for growth, periodically can be dominating species in coastal waters (Lindahl \& Hernroth 1983). Furthermore, extensive $\mathrm{pH}$ and DIC data already exist for the species C. lineatum (Hansen 2002, Rost et al. 2006, Hansen et al. 2007), which facilitate comparisons of the species within the genus and provide additional information regarding their carbon acquisition. Rost et al. (2006) have demonstrated that $C$. lineatum is able to use $\mathrm{HCO}_{3}{ }^{-}$and that direct $\mathrm{HCO}_{3}{ }^{-}$uptake accounts for $85 \%$ of the carbon uptake even at $\mathrm{pH} 8$.

The aim of the present study was to examine the effects of high $\mathrm{pH}$ on growth rates of 3 species of Ceratium (C. furca, C. fusus and C. tripos) and to establish upper $\mathrm{pH}$ limits for growth and survival. This has been done by (1) using different constant pH levels and (2) allowing the algae themselves to generate a drifting $\mathrm{pH}$ due to their uptake of inorganic carbon. The results of the 2 methods were compared, since both methods have previously been used to describe $\mathrm{pH}$ effects on phytoplankton (e.g. Hinga 2002). Three species of the same genus covering a wide range of cell volumes have been chosen to elucidate a possible relationship between size and $\mathrm{pH}$ tolerance.

Since the effects of high $\mathrm{pH}$ could be indirect due to low (photosynthetically available) DIC concentrations, the DIC limits for growth were also examined for Ceratium furca. The results were used to separate the effects of high pH and low DIC. Finally, the effects of light were investigated to examine whether an increased $\mathrm{pH}$ tolerance would occur when more energy was provided in the form of light (Bartual \& Gálvez 2002). An increased pH tolerance could occur if growth at high $\mathrm{pH}$ is more energy demanding, due to an extra energy cost when using $\mathrm{HCO}_{3}{ }^{-}$as carbon substrate or due to an extra energy demand in order to maintain a stable internal $\mathrm{pH}$.

\section{MATERIALS AND METHODS}

Culture and general experimental conditions. Three species of the dinoflagellate genus Ceratium were used in this study. The origin and isolation dates of these cultures are given in Table 1. The cultures (non-axenic) were kept in $250 \mathrm{ml}$ Nunclon flasks at $15 \pm 1^{\circ} \mathrm{C}$, and mounted on a plankton wheel with $1 \mathrm{rpm}$ at a photon flux density of $100 \mu \mathrm{m}$ photons $\mathrm{m}^{-2} \mathrm{~s}^{-1}$ in a 16:8 h light:dark cycle. Illumination was provided by cool white fluorescent lamps and irradiance was measured using a Li-1000, Li-Cor sensor, equipped with a spherical probe. The growth medium consisted of autoclaved seawater with a salinity of $30 \pm 1$ psu enriched with $f / 2$ nutrients added after autoclaving (Guillard 1983).

Measurements of cell density were done according to Utermöhl (1958), and algal growth rates were calculated assuming exponential growth: $\mu\left(\mathrm{d}^{-1}\right)=\left(\ln N_{1}-\right.$ $\left.\ln N_{0}\right) / t$, where $N_{0}$ and $N_{1}$ are the cell concentrations per millilitre at time $t_{0}$ and $t_{1}$, respectively, and $t$ is the difference in time (d) between $t_{0}$ and $t_{1}$ samples. Dilutions were taken into account by subtracting the removed amount of cells after each sampling occasion. A minimum of 400 cells was counted at all sampling occasions, except in the case of negative growth at high $\mathrm{pH}$. At these occasions it was not possible to remove such large quantities of medium as to provide 400 cells, but instead a volume of $10 \mathrm{ml}$ was counted. This rather large volume ensured that the standard error (SE) was kept within reasonable limits (maximum SE was 0.06). In all experiments, a 2 d lag phase was excluded from the growth rate calculations to ensure that exponential growth was obtained.

The $\mathrm{pH}$ of the culture medium was measured with Sentron Isfet $\mathrm{pH}$ meters with Red line or Argus $\mathrm{X}$ probes, which were calibrated using $\mathrm{pH}$ buffers 7 and 10. Total concentration of DIC was measured using an infrared gas analyser, IRGA (ADC, MK3). Water sam-

Table 1. Ceratium spp. Maximum growth rates and upper $\mathrm{pH}$ limits for growth $( \pm \mathrm{SD})$

\begin{tabular}{|lccc|}
\hline & C. fusus & C. furca & C. tripos \\
\hline Max. growth rate $\left(\mathrm{d}^{-1}\right)$ & 0.32 & 0.26 & 0.14 \\
Max. pH for growth (constant $\mathrm{pH})$ & 8.73 & 9.08 & 8.92 \\
Max. pH for growth (pH drift) & $8.76( \pm 0.02)$ & $8.82( \pm 0.01)$ & $8.85( \pm 0.03)$ \\
Sampling location, year & The Sound, 2003 & The Sound, 2003 & The Sound, 1995 \\
Donor & L. M. Søderberg & L. M. Søderberg & P. J. Hansen \\
\hline
\end{tabular}


ples $(80 \mu l)$ were injected into a small chamber containing $\mathrm{HNO}_{3}(20 \mathrm{mM})$, and the liberated $\mathrm{CO}_{2}$ gas was transferred to the IRGA using nitrogen gas as a carrier.

Constant pH experiments with 3 species of Ceratium. In the constant $\mathrm{pH}$ experiments both the $\mathrm{pH}$ (and the total DIC concentration) was largely held constant during incubation because of the low cell concentrations (initial concentration 15 cells ml$^{-1}$ ). The initial total DIC concentration was between 1.6 and $1.7 \mathrm{mM}$. The $\mathrm{pH}$ was manipulated at the start of the experiment by the addition of $1 \mathrm{M} \mathrm{NaOH}$. At the highest $\mathrm{pH}$ levels of $8.8,9.0$ and 9.2 , the $\mathrm{pH}$ was gradually elevated for 1 to $2 \mathrm{~d}$ prior to the experiment. Experiments were carried out in triplicate. Every second day, $10 \mathrm{ml}$ samples were removed and fixed with Lugol's iodine for enumeration. Growth rates are based on 3 or 4 consecutive cell counts. The flasks were refilled to capacity, and $\mathrm{pH}$ was adjusted with small amounts of $1 \mathrm{M} \mathrm{NaOH}$ or $\mathrm{HCl}$ in order to keep the $\mathrm{pH}$ constant $(\mathrm{pH}$ was adjusted to $\pm 0.02 \mathrm{pH}$ units every second day). In between adjustments the $\mathrm{pH}$ varied by a maximum of \pm 0.1 in the individual flasks, except at $\mathrm{pH} 7.5$ when the $\mathrm{pH}$ increased during the experiments from 7.45 to 7.96 for $C$. furca and to 7.67 for $C$. tripos.

pH drift experiments with 3 species of Ceratium. In the $\mathrm{pH}$ drift experiments the algae decrease the total DIC pool as the population proliferates and $\mathrm{pH}$ increases. The initial total DIC concentration was between 1.6 and $1.7 \mathrm{mM}$. Experiments were performed using 3 or 4 replicates. The initial $\mathrm{pH}$ was around 8 (7.95 to 8.15), and the experiments were terminated when the algae went into stationary growth phase and no further increase in $\mathrm{pH}$ was observed. The initial concentration was 15 cells ml $^{-1}$ for C. fusus, 25 cells $\mathrm{ml}^{-1}$ for C. tripos and 50 cells $\mathrm{ml}^{-1}$ for the experiment with $C$. furca. Every second or third day (around noon), the pH was measured and 5 to $10 \mathrm{ml}$ samples were removed and fixed for enumeration. The flasks were refilled with medium of the same $\mathrm{pH}$ $( \pm 0.05 \mathrm{pH}$ units).

At termination of the experiment with Ceratium furca, the medium was filtered (GF/C glass microfiber filters) and frozen for later analysis of inorganic nutrients ( $\mathrm{N}$ and $\mathrm{P}$ ) to ensure that no nutrient limitation had occurred during the experiments. $\mathrm{NO}_{2}{ }^{-}, \mathrm{NO}_{3}{ }^{-}, \mathrm{NH}_{4}{ }^{+}$ and $\mathrm{PO}_{4}{ }^{3-}$ were analysed according to Valderrama (1995). In order to follow the decrease in the DIC pool, the total DIC was measured every second or third day for the $\mathrm{pH}$ drift experiment with $C$. furca.

An extra set of $\mathrm{pH}$ drift experiments was carried out to ensure that the growth rates during the $\mathrm{pH}$ drift experiments were not affected by lack of vitamins $\left(B_{12}\right.$, thiamine, or biotin). In the original recipe by Guillard (1983), it is recommended that both the stock solution and the working solution of vitamins are autoclaved.
This procedure could possibly affect the quality of the vitamins, and for this reason a working stock solution based on non-autoclaved vitamins was tested. The non-autoclaved vitamin solution was prepared with autoclaved distilled water and stored in the freezer in small Eppendorf tubes until use. The effects of the 2 methods were studied in drift $\mathrm{pH}$ experiments with Ceratium furca. Both vitamin solutions were added to the media after autoclaving.

Growth rate of Ceratium furca at different DIC concentrations. C. furca was selected for this experiment. Both DIC and $\mathrm{pH}$ were kept constant during the experiment, which was performed at $\mathrm{pH} 8.0$ and 9.0. The initial cell concentration was 15 cells ml ${ }^{-1}$. The experiment was carried out in triplicate. Different DIC concentrations were used ranging from 0.2 to $3.4 \mathrm{mM}$ DIC. In order to achieve the low DIC concentrations (below $1.6 \mathrm{mM}$ ), the $\mathrm{pH}$ was lowered to $\mathrm{pH} 3$ by addition of $1 \mathrm{M} \mathrm{HCl}$, and aerated until the $\mathrm{CO}_{2}$ had gassed off. The DIC-enhanced medium was obtained by adding $0.5 \mathrm{M} \mathrm{HCO}_{3}{ }^{-}$. Every second day $10 \mathrm{ml}$ samples were removed for enumeration, and additional $2 \mathrm{ml}$ samples were removed for DIC analysis. The flasks were refilled to capacity, and $\mathrm{pH}$ was adjusted to maintain the desired level. The $\mathrm{pH}$ was adjusted to \pm 0.05 every second day and varied by a maximum of \pm 0.16 between adjustments. The DIC concentrations were converted to photosynthetically available inorganic carbon $\left(\mathrm{CO}_{2}+\mathrm{HCO}_{3}^{-}\right)$for a better comparison of $\mathrm{pH}$ 8.0 and 9.0, since the speciation of inorganic carbon is highly $\mathrm{pH}$ dependent. The amount of photosynthetically available inorganic carbon was calculated according to Plath et al. (1980) and Mackereth et al. (1978).

Effects of irradiance on the $\mathrm{pH}$ tolerance for growth. This experiment was also carried out using Ceratium furca as a test organism. The DIC concentration was largely held constant, due to the low cell concentrations (initial concentration 15 to 30 cells ml $^{-1}$ ). The initial total DIC concentration was 1.4 to $1.7 \mathrm{mM}$ in this experiment, and this did not change in the individual bottles during incubation. The $\mathrm{pH}$ was gradually elevated (during $2 \mathrm{~d}$ ) prior to the start of the experiment by addition of $1 \mathrm{M} \mathrm{NaOH}$. Experiments were carried out in triplicate. Every second day $10 \mathrm{ml}$ samples were removed for enumeration. The flasks were refilled to capacity, and $\mathrm{pH}$ was adjusted with small amounts of $1 \mathrm{M} \mathrm{NaOH}$ or $\mathrm{HCl}$ in order to keep pH constant. The tested light regimes were 25 and $200 \mu \mathrm{m}$ photons $\mathrm{m}^{-2} \mathrm{~s}^{-1}$ to ensure both subsaturating and saturating photon flux densities, on a 16:8 h light:dark basis. At both light intensities a $\mathrm{pH}$ range of 8.15 to 9.15 was tested. The algae were adapted to the appropriate photon flux density for at least $5 \mathrm{~d}$ prior to the experiment. 


\section{RESULTS}

\section{Constant pH experiments}

The upper $\mathrm{pH}$ limits for growth using the constant $\mathrm{pH}$ approach were 8.73, 8.92 and 9.08 for Ceratium fusus, C. tripos and C. furca, respectively (see Table 1 for further results). A sharp decline in growth rates was observed within $0.1 \mathrm{pH}$ unit of the upper $\mathrm{pH}$ limit (Fig. 1). The lower $\mathrm{pH}$ limits for growth of the Ceratium species were not determined, but no significant differences were observed in the growth rates at $\mathrm{pH} \sim 7.5$ compared to the growth rates at $\mathrm{pH} \sim 8.0$ for any of the 3 species ( $\mathrm{p}>0.05$, Students' $t$-test).
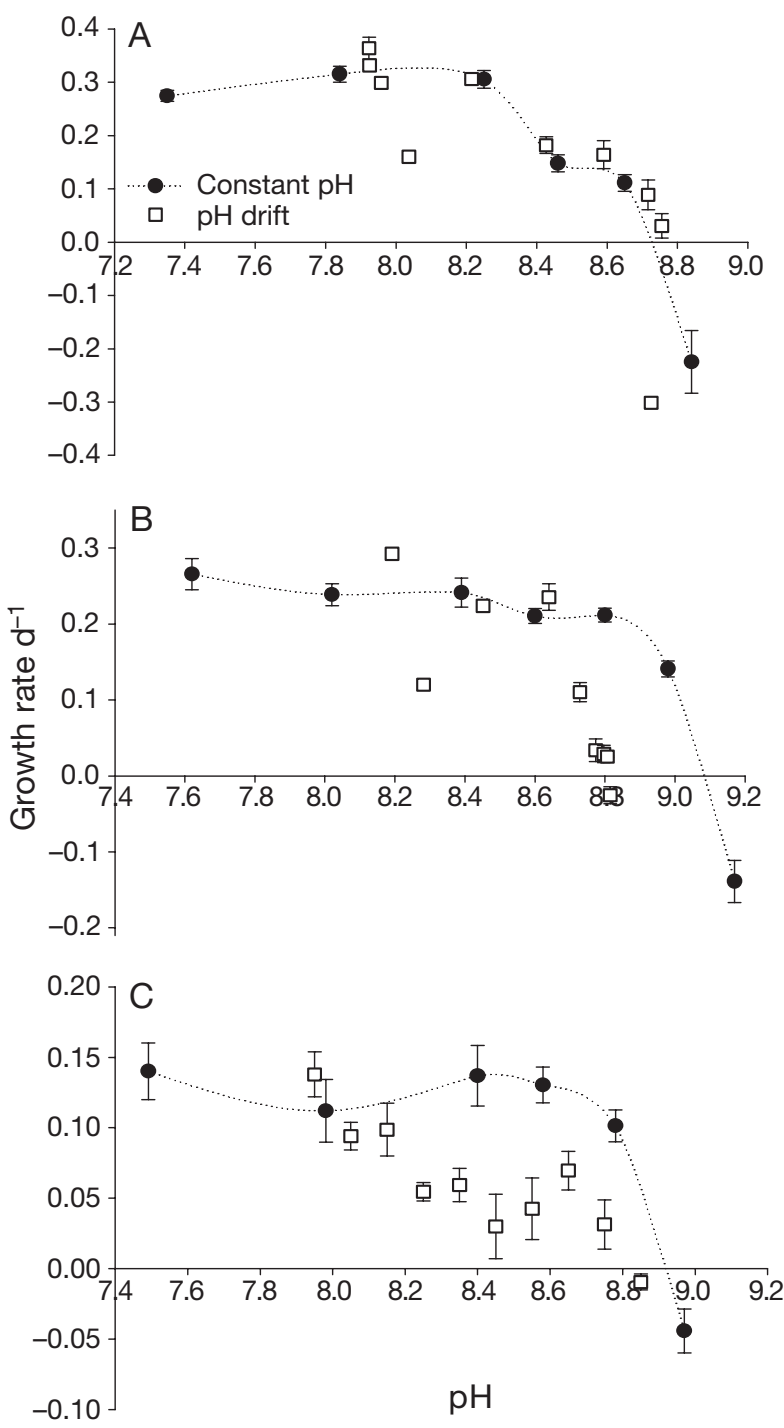

Fig. 1. Ceratium spp. $\mathrm{pH}$ drift and $\mathrm{pH}$ constant experiments for (A) C. fusus, (B) C. furca and (C) C. tripos. For C. tripos, data points represent data pooled within $0.1 \mathrm{pH}$ units. Error bars $=\mathrm{SE}$

\section{pH drift experiments}

The upper $\mathrm{pH}$ limit for growth obtained in the $\mathrm{pH}$ drift experiments was approximately 8.8 for all 3 species (Fig. 1). For the 2 largest species, Ceratium tripos and $C$. furca, these upper $\mathrm{pH}$ limits for growth were lower than those obtained in the $\mathrm{pH}$ constant experiments, while the $\mathrm{pH}$ limit for the smallest species, $C$. fusus, was the same irrespective of the approach used (Fig. 1, Table 1). Consult Table 2 for cell sizes.

In case of the largest species, Ceratium tripos, the growth rate started to decline at $\mathrm{pH} 8.25$ in the $\mathrm{pH}$ drift experiment, while a reduction in growth rate in the constant $\mathrm{pH}$ experiment was not observed before $\mathrm{pH}$ had exceeded pH 8.8 (Fig. 1C). The growth of $C$. furca was unaffected up to $\mathrm{pH} 8.65$ in the $\mathrm{pH}$ drift experiment, but the growth rate declined dramatically between pH 8.7 and 8.8 (Fig. 1B). Thus, for C. furca, the growth rates observed in the $\mathrm{pH}$ drift and constant $\mathrm{pH}$ experiments only differed at high $\mathrm{pH}$. As opposed to C. tripos and C. furca, the $\mathrm{pH}$ drift and constant $\mathrm{pH}$ experiments for $C$. fusus yielded almost identical results with regard to the $\mathrm{pH}$-dependent growth rate (Fig. 1A).

To ensure that $\mathrm{pH}$ was the only limiting factor in the $\mathrm{pH}$ drift experiment, inorganic macronutrients ( $\mathrm{N}$ and $\mathrm{P}$ ) and DIC were analysed at the end of the $\mathrm{pH}$ drift experiment (Ceratium furca). Table 3 shows that $\mathrm{N}$ and $\mathrm{P}$ remained in excess during the experiment. The final total DIC concentration in the $\mathrm{pH}$ drift experiment was $1.2 \mathrm{mM}$, which at $\mathrm{pH} 8.82$ corresponds to $0.91 \mathrm{mM}$ photosynthetically available DIC $\left(=\mathrm{CO}_{2}+\mathrm{HCO}_{3}{ }^{-}\right)$ (Table 4).

Furthermore, the quality of the vitamin solutions was examined by comparing the 2 different methods of preparing vitamin solutions (with/without heat treatment). The 2 methods gave very similar results (Fig. 2), and neither growth rates nor $\mathrm{pH}$ were significantly different at the termination of the experiment $(p>0.05$, Students' $t$-test). Thus, the quality of the autoclaved vitamins was not affected to an extent that it became limiting for the growth of Ceratium furca.

\section{Growth rate of Ceratium furca at different DIC concentrations}

To test if the final DIC concentrations in the $\mathrm{pH}$ drift experiment were limiting for the growth of the larger Ceratium species, an experiment was carried out with C. furca in which the growth dependency of DIC at pH 8.0 and 9.0 was studied. Carbon concentrations remained constant during the experiments (Fig. 3). The results clearly show that the growth of $C$. furca is $\mathrm{pH}$ limited at $\mathrm{pH} 9.0$, even at very high photosyntheti- 
Table 2. Ceratium spp. Measured sizes $( \pm \mathrm{SD})$. Volume and surface areas are calculated using simple geometric formulae according to Hillebrand et al. (1999), with minor modifications (for C. fusus both the hypothecal and the apical horn have been calculated as cylinders). The calculations are based on microscopic measurements of 10 to 20 live cells from each species sampled in the exponential phase

\begin{tabular}{|lccc|}
\hline & C. fusus & C. furca & C. tripos \\
\hline Volume $\left(\mu \mathrm{m}^{3}\right)$ & $31000( \pm 6330)$ & $68000( \pm 14432)$ & $111000( \pm 11656)$ \\
Surface area $\left({\left.\mu \mathrm{m}^{2}\right)}\right)$ & 26000 & 37000 & 51000 \\
Surface:volume ratio & 0.83 & 0.55 & 0.46 \\
\hline
\end{tabular}

Table 3. Ceratium furca. Macronutrient concentrations ( $\mathrm{N}$ and $\mathrm{P}$ ) at the beginning and at the termination of the $C$. furca $\mathrm{pH}$ drift experiment $( \pm \mathrm{SD}, \mathrm{n}=3)$. n.a.: $\mathrm{SD}$ is not available, since $\mathrm{n}=1$, due to sampling error

\begin{tabular}{|lccc|}
\hline & $\mathrm{NO}_{3}+\mathrm{NO}_{2}(\mu \mathrm{M})$ & $\mathrm{NH}_{4}(\mu \mathrm{M})$ & $\mathrm{PO}_{4}(\mu \mathrm{M})$ \\
\hline Start concentration & $1010.47( \pm 0.73)$ & $0.73($ n.a. $)$ & $45.74( \pm 0.10)$ \\
Final concentration & $943.74( \pm 9.26)$ & $0.90( \pm 0.17)$ & $35.31( \pm 1.44)$ \\
\hline
\end{tabular}

Table 4. Ceratium furca. Carbon data for the $\mathrm{pH}$ drift experiment with $C$. furca $( \pm \mathrm{SD})$. DIC: dissolved inorganic carbon

\begin{tabular}{|lcccc|}
\hline & $\begin{array}{c}\mathrm{CO}_{2} \\
(\mathrm{mM})\end{array}$ & $\begin{array}{c}\mathrm{HCO}_{3}{ }^{-} \\
(\mathrm{mM})\end{array}$ & $\begin{array}{c}\mathrm{CO}_{2}+\mathrm{HCO}_{3}{ }^{-} \\
(\mathrm{mM})\end{array}$ & $\begin{array}{c}\text { Total DIC } \\
(\mathrm{mM})\end{array}$ \\
\hline Start carbon conc. (pH 8.13) & 0.013 & 1.46 & 1.48 & $1.57( \pm 0.01)$ \\
Final carbon conc. (pH 8.82) & 0.002 & 0.90 & 0.91 & $1.20( \pm 0.05)$ \\
\hline
\end{tabular}

cally available inorganic carbon concentrations. However, the data also demonstrate that the ability of C. furca to grow at low photosynthetically available inorganic carbon concentrations depends on $\mathrm{pH}$.

The growth rate at $\mathrm{pH} 8$ is constant at a photosynthetically available inorganic carbon concentration above $0.5 \mathrm{mM}$. At a concentration of $0.2 \mathrm{mM}$, the cells

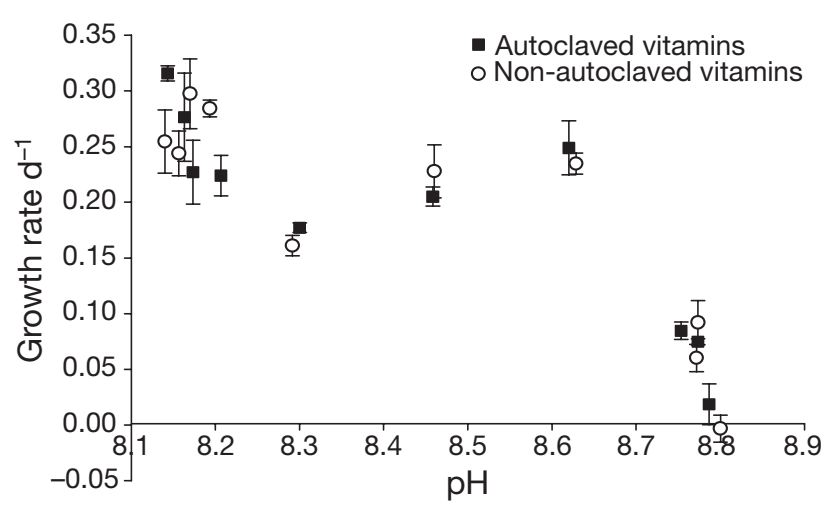

Fig. 2. Ceratium furca. Autoclaved and non-autoclaved vitamins in $\mathrm{pH}$ drift experiments with $C$. furca. Error bars = SE are still able to grow at approximately half the maximum growth rate; thus, DIC limitation of the growth rate at $\mathrm{pH}$ 8 does not take place unless the DIC concentration is very low. At $\mathrm{pH}$ 9.0, on the other hand, Ceratium furca is not able to grow until the photosynthetically available inorganic carbon concentration exceeds approximately $0.8 \mathrm{mM}$, corresponding to a total DIC concentration of $1.2 \mathrm{mM}$. Thus, the final photosynthetically available DIC concentration of the $\mathrm{pH}$ drift experiment (0.91 mM, see Table 4) approaches the DIC limit for growth at pH 9.0.

\section{Effects of irradiance on the pH tolerance for growth}

Since the DIC limit for growth was higher at $\mathrm{pH} 9$ than at $\mathrm{pH} 8$, it could be due to an extra energy cost when converting $\mathrm{HCO}_{3}{ }^{-}$to $\mathrm{CO}_{2}$ inside the cell or that direct $\mathrm{HCO}_{3}{ }^{-}$uptake is a more energy-demanding process than $\mathrm{CO}_{2}$ uptake. For this reason, the effects of light on the growth rate were studied.

The growth rate of Ceratium furca at $200 \mu \mathrm{mol}$ photons $\mathrm{m}^{-2} \mathrm{~s}^{-1}$ was $0.24 \mathrm{~d}^{-1}$ (Fig. 4), which is the same growth rate as was observed at 100 photons $\mathrm{m}^{-2} \mathrm{~s}^{-1}$ in the constant $\mathrm{pH}$ experiment (both at $\mathrm{pH}$ 8.0). Thus, the growth rate of $C$. furca was saturated at $\leq 100$ photons $\mathrm{m}^{-2} \mathrm{~s}^{-1}$. The corresponding growth rate at $25 \mu \mathrm{mol}$ photons $\mathrm{m}^{-2} \mathrm{~s}^{-1}$ was $0.14 \mathrm{~d}^{-1}$ (at $\mathrm{pH}$ 8.0). The growth rates remained constant up to $\mathrm{pH}$

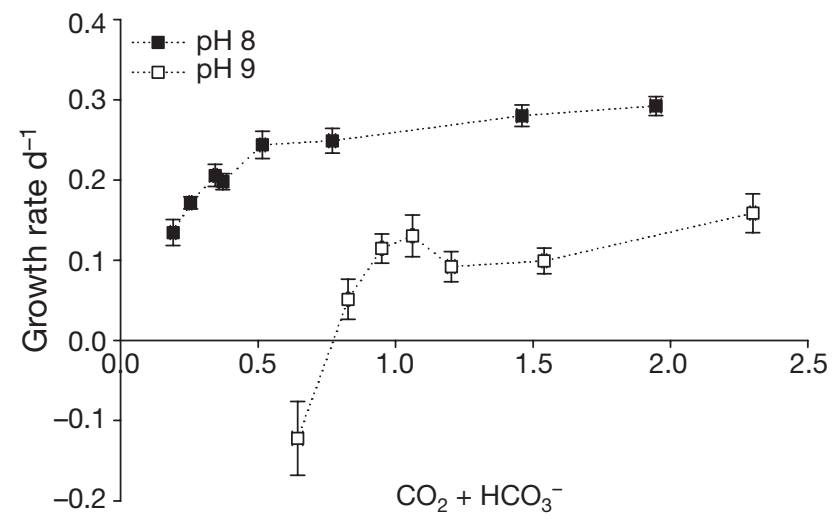

Fig. 3. Ceratium furca. Effects of photosynthetically available dissolved inorganic carbon on the growth rate of $C$. furca. Vertical error bars $=\mathrm{SE}(\mathrm{n}=12)$; horizontal error bars $(\mathrm{SE})$ are covered by the data points 


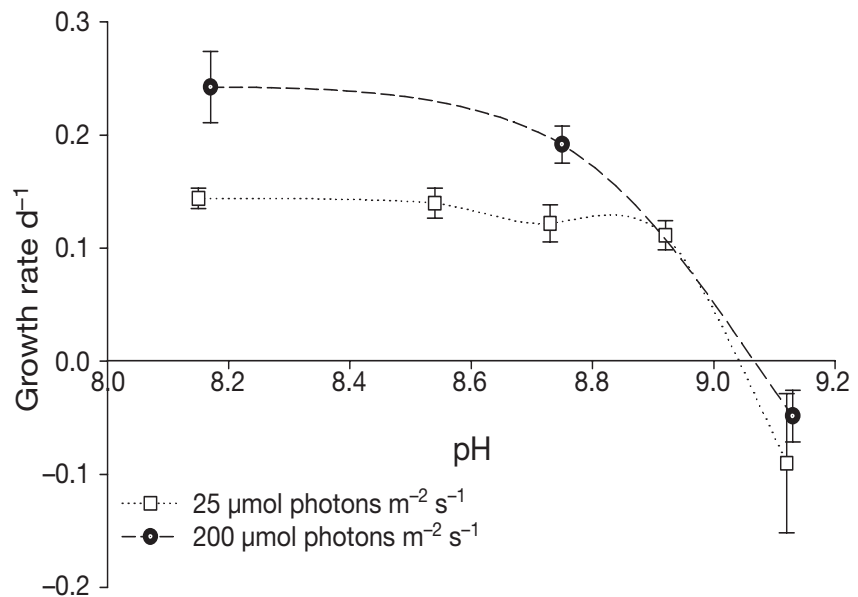

Fig. 4. Ceratium furca. Effects of light on the growth rate of C. furca. Error bars = SE $(\mathrm{n}=9)$

8.7-8.9 at both 25 and $200 \mu \mathrm{mol}$ photons $\mathrm{m}^{-2} \mathrm{~s}^{-1}$, and at both irradiances the growth rates approached zero around pH 9.05 to 9.10. Even though the data points at $200 \mu \mathrm{mol}$ photons $\mathrm{m}^{-2} \mathrm{~s}^{-1}$ are scarce, the observed change in light intensity did not alter the $\mathrm{pH}$ tolerance of $C$. furca and the growth rates for the 2 different light regimes did not differ significantly at pH 9.15 (MannWhitney $U$-test, $>0.05$ ).

\section{DISCUSSION}

\section{Upper pH limits for Ceratium spp.}

The upper $\mathrm{pH}$ limit for growth in the $\mathrm{pH}$ drift experiments was approximately 8.8 for all the Ceratium species tested. These $\mathrm{pH}$ limits for growth are significantly higher than the previously reported upper $\mathrm{pH}$ limits for growth of 8.3 and 8.4 for C. tripos and C. furca, respectively (Schmidt \& Hansen 2001). The experimental conditions in Schmidt and Hansen's study are comparable to the present study, but the low growth rates of C. tripos and C. furca combined with frequent sampling and subsequent dilutions in their study could have prevented a true stationary growth phase and a maximum obtainable $\mathrm{pH}$. In the present study, the ability to measure even very low growth rates has been increased due to longer periods of time between the samplings. Of course it is not possible to completely rule out clone variations, but the C. tripos strain used in both studies is the same.

In contrast, the upper $\mathrm{pH}$ limits for growth obtained in the constant $\mathrm{pH}$ experiment (Table 1) are comparable to the results obtained by Pedersen \& Hansen (2003a) using natural plankton communities grown in natural seawater at different constant $\mathrm{pH}$ levels.

\section{Two different methods for determining $\mathrm{pH}$ tolerance for growth}

In the present study, 2 different methods (constant $\mathrm{pH}$ and drift $\mathrm{pH}$ ) were used to test the $\mathrm{pH}$ limits for growth, and the results demonstrate that the 2 methods do not always produce comparable results. But why do the 2 methods give a different outcome in some cases?

An important difference between the 2 types of experiments is the cell density. The cell density is low throughout the constant $\mathrm{pH}$ experiment, due to low initial cell concentrations and the short duration of the experiment. For the $\mathrm{pH}$ drift experiments, on the other hand, the final cell concentrations were $~ 700,950$ and 1300 cells ml ${ }^{-1}$ for Ceratium tripos, C. furca and C. fusus, respectively. The $\mathrm{pH}$ in high-density cultures is susceptible to daily variations, and an experiment with the dinoflagellate Heterocapsa triquetra reveals that $\mathrm{pH}$ in laboratory cultures can vary as much as $0.2 \mathrm{pH}$ units during the day (Havskum \& Hansen 2006). The $\mathrm{pH}$ was measured at noon in the present $\mathrm{pH}$ drift experiments, and the $\mathrm{pH}$ could thus have increased a further 0.1 to $0.15 \mathrm{pH}$ units during the afternoon and evening. This daily $\mathrm{pH}$ variation would not have occurred in the constant $\mathrm{pH}$ experiments due to the lower cell densities. Thus, some of the observed differences between the $\mathrm{pH}$ drift and constant $\mathrm{pH}$ experiments might be explained by diurnal $\mathrm{pH}$ variations. This might explain the results for C. furca, but it also raises the question as to why $C$. fusus then do not show a similar response.

The high cell concentrations could theoretically result in depletion of nutrients, vitamins, light, or inorganic carbon. Regarding nutrients, both macro- and micronutrients were added in excess and at the end of the $\mathrm{pH}$ drift experiment with Ceratium furca, inorganic $\mathrm{N}$ and $\mathrm{P}$ were still available in excess (Table 3). Most dinoflagellates are in need of vitamins $B_{12}$, thiamine, or biotin (Gaines \& Elbrächter 1987), but the different treatments of the vitamins did not result in different growth rates, and therefore it can be concluded that vitamins were not the limiting factor in our $\mathrm{pH}$ drift experiment.

The experimental irradiance $\left(100 \mu \mathrm{m}\right.$ photons $\mathrm{m}^{-2}$ $\mathrm{s}^{-1}$ ) was based on unpublished data by P. J. Hansen \& T. G. Nielsen on the growth rate of Ceratium furca, $C$. tripos and $C$. fusus under different light regimes to ensure saturating light conditions with regard to growth rates. Since the growth rate of $C$. furca in the present experiments was the same at 100 and $200 \mu \mathrm{m}$ photons $\mathrm{m}^{-2} \mathrm{~s}^{-1}$, irradiance was not a limiting factor in the $\mathrm{pH}$ drift experiments. Moreover, the experiments carried out at 2 different irradiances resulted in the same $\mathrm{pH}$ limit for growth for C. furca. Thus, light limitation cannot have been the reason for the lower $\mathrm{pH}$ tolerances observed in the $\mathrm{pH}$ drift experiment. 
Finally, the DIC concentration was measured during the $\mathrm{pH}$ drift experiment with Ceratium furca, and the final DIC concentration was compared to the DIC limits for growth at pH 8 and 9 (Table 4, Fig. 3). The latter experiment demonstrates that the final DIC concentration in the $\mathrm{pH}$ drift experiment for $C$. furca does, in fact, approach the DIC limit at pH 9 and hence a co-limitation of $\mathrm{pH}$ and $\mathrm{DIC}$ in the $\mathrm{pH}$ drift experiment is a possible explanation for the different results in the 2 types of experiments. Under the assumption that $C$. furca, $C$. tripos and C. fusus, like C. lineatum, are able to use $\mathrm{HCO}_{3}{ }^{-}$as a carbon source, a combined limitation of high $\mathrm{pH}$ and low DIC applies for both C. furca and $C$. tripos at the end of the $\mathrm{pH}$ drift experiment. This is in contrast to C. fusus, which in our experiments is limited exclusively by $\mathrm{pH}$, since the $\mathrm{pH}$ drift and the constant $\mathrm{pH}$ experiment yielded similar results.

\section{Effects of irradiance on the upper $\mathrm{pH}$ limits for growth}

The combined effects of light, DIC and pH on growth rates have, to our knowledge, not been studied on Ceratium spp. or any other dinoflagellate, but Bartual \& Gálvez (2002) have examined the effects of light, DIC and $\mathrm{pH}$ on the diatom Phaeodactylum tricornutum. They found that the growth rate was significantly reduced at high $\mathrm{pH}$ and low DIC at subsaturating light intensities. Similarly, the growth rate remained constant at both high $\mathrm{pH}$ and low DIC at high light intensities. The authors suggest that this can be explained by an energy-demanding uptake of $\mathrm{HCO}_{3}{ }^{-}$and that a competition between $\mathrm{N}$ metabolism and $\mathrm{C}$ metabolism is observed under subsaturating light. These results are in contrast with the present results in which different light regimes did not result in different $\mathrm{pH}$ limits for growth. For C. furca, it does not seem that growth at high $\mathrm{pH}$ is more energy demanding than growth at $\mathrm{pH}$ 8. Whether this is due to fixed $\mathrm{HCO}_{3}{ }^{-}$and $\mathrm{CO}_{2}$ proportions of the cell's total carbon uptake at changing $\mathrm{pH}$ levels or whether the $\mathrm{HCO}_{3}{ }^{-}$uptake does not require more energy than $\mathrm{CO}_{2}$ uptake is speculative. But it can be concluded that the carbon uptake at high $\mathrm{pH}$ is not limited by lack of energy.

A possible effect of high $\mathrm{pH}$ could instead be less efficient proton pumps which, in turn, could result in lack of regulation of the internal $\mathrm{pH}$ and lack of control of pH-sensitive enzymatic processes or lead to cell leakage (Raven 1980, Taraldsvik \& Myklestad 2000).

\section{Natural pH and natural DIC concentrations}

Are our conclusions still relevant when extrapolating from laboratory to nature? The $\mathrm{pH}$ of marine waters has historically not received much attention, but recent research demonstrates that the $\mathrm{pH}$ of fjords and lagoons can rise to as high as 9.5 during summer (Macedo et al. 2001, Hansen 2002). But to what extent are these $\mathrm{pH}$ increases just single incidents during extraordinary blooms? It is important to distinguish between oceanic and coastal areas, since recent data prove that high $\mathrm{pH}(\geq 9)$ is a common phenomenon in coastal waters during the summer months: In Mariager Fjord, Denmark, the median $\mathrm{pH}$ is close to 9 during the summer (May to August) every year (Hansen 2002). In the German Bight, $\mathrm{pH}$ values of 8.7 were measured in May and June 1986 (Kempe \& Pegler 1991), and, in the Southern Bight of the North Sea, the $\mathrm{pH}$ was reported to rise from 7.9 to 8.7 during an intense Phaeocystis bloom (Brussaard et al. 1996). In contrast, the open oceans are in general oligotrophic and thus significant $\mathrm{pH}$ fluctuations are not expected to occur (Clark \& Flynn 2000). Besides the seasonal $\mathrm{pH}$ variations in coastal waters, diurnal variations are also reported to take place. Diurnal $\mathrm{pH}$ variations are not restricted to dense laboratory cultures; in closed or small bodies of water the $\mathrm{pH}$ can vary from 8.2 to 8.9 during the day due to photosynthesis and respiration (Millero 1996). In conclusion, Ceratium spp. and other phytoplankton species with $\mathrm{pH}$ limits for growth $\leq 9$ will experience $\mathrm{pH}$ limitations in coastal waters, and $\mathrm{pH}$ is thus an important factor in the regulation of coastal phytoplankton species composition. In the waters surrounding Denmark, Ceratium spp. are often the dominant species in the late summer phytoplankton. However, it is missing in many eutrophic Danish fjords and bays, even though chemical and physical parameters suggest that they ought to be present (Jensen 1994). High $\mathrm{pH}$ is thus a likely contributing factor for the distribution of Ceratium, and should as such be taken into consideration.

Naturally, for the $\mathrm{pH}$ to increase, the DIC must be depleted faster than $\mathrm{CO}_{2}$ equilibration with the atmosphere. Therefore, the $\mathrm{pH}$ drift experiment was designed to mimic the coexisting $\mathrm{pH}$ rise and $\mathrm{CO}_{2}$ depletion in nature during phytoplankton blooms. The total DIC concentrations in marine waters correlate in general with salinity; the higher the salinity, the higher the DIC (Thomas \& Schneider 1999). The typical DIC concentration in oceanic waters is approximately $2.2 \mathrm{mM}$. In brackish waters like, for example, the Baltic Sea (salinity $\sim 4$ to $31 \mathrm{psu}$ ), the DIC concentration varies from approximately 1.2 to $2.2 \mathrm{mM}$ (Thomas \& Schneider 1999). Thus, the initial DIC concentrations of 1.6 to $1.7 \mathrm{mM}$ in the $\mathrm{pH}$ drift experiment are representative of many estuarine areas. The above-mentioned natural DIC concentrations represent situations in which the $\mathrm{CO}_{2}$ is close to air-sea equilibrium, and thus much lower DIC concentrations can occur during blooms (Codispoti et al. 1982), especially in nutrient-enriched 
sheltered waters, such as bays, lagoons and fjords. However, additional data on DIC concentrations and $\mathrm{pH}$ in coastal waters during blooms are much needed.

Based on these inorganic carbon concentrations found in nature and the DIC requirements of Ceratium furca, it is unlikely that $C$. furca will experience DIC limitation in nature at $\mathrm{pH} 8.0$ to 8.2. In contrast, at $\mathrm{pH}$ 9.0, the total DIC limit for C. furca is as high as $1.2 \mathrm{mM}$ and a combined $\mathrm{pH} / \mathrm{DIC}$ limitation at high $\mathrm{pH}$ is therefore possible in nature.

Thus, it seems likely that small Ceratium species in nature will often experience growth limitations by high $\mathrm{pH}$ and that larger Ceratium species most likely will experience a combined $\mathrm{pH} / \mathrm{DIC}$ limitation at high $\mathrm{pH}$.

\section{Upper pH limits for dinoflagellates - Does size matter?}

For Ceratium furca and C. tripos it is worth noticing that not only are the final $\mathrm{pH}$ in the $\mathrm{pH}$ drift experiments different from the maximum tolerable $\mathrm{pH}$ found in the constant $\mathrm{pH}$ experiments, but the growth rates measured during the $\mathrm{pH}$ drift experiment are affected at an earlier stage; this especially applies to $C$. tripos (Fig. 1C). These results indicate a size dependency in the ability to maintain a constant growth rate during drifting $\mathrm{pH}$ and concomitant DIC depletion. This apparent DIC limitation at high $\mathrm{pH}$ could be due to different abilities in inorganic carbon uptake or in the ability to minimize carbon leakage.
A possible size dependency of $\mathrm{pH}$ tolerances could be explained by the difference in the surface:volume ratio, in the same way that smaller cells have a more efficient nutrient uptake due to their larger surface:volume ratio (Raven 2003). Data on the smaller Ceratium lineatum

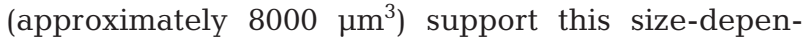
dency hypothesis, since $\mathrm{pH}$ drift and $\mathrm{pH}$ constant experiments give the same $\mathrm{pH}$ tolerances for growth (Schmidt \& Hansen 2001, Hansen 2002). Furthermore, pH drift experiments with $C$. lineatum using varying initial DIC concentrations resulted in similar $\mathrm{pH}$ values in the stationary phase and hence indicate that $\mathrm{pH}$ was the main limiting factor (Hansen et al. 2007).

Growth limitation by high $\mathrm{pH}$ is thus a relevant issue for Ceratium spp., but does this apply to dinoflagellates in general? For dinoflagellates as a group the currently published $\mathrm{pH}$ limits for growth vary from 8.7 to 10.1 (Table 5) and thus cover almost the whole range of $\mathrm{pH}$ tolerances at present known to apply to phytoplankton (see Hansen 2002). The $\mathrm{pH}$ limits for growth of C. tripos, C. furca and C. fusus are accordingly among the lowest measured dinoflagellate $\mathrm{pH}$ tolerances for growth. Nevertheless, $\mathrm{pH}$ tolerances for growth $\leq 9$ are not uncommon for dinoflagellates.

For diatoms, it seems that small species have a higher $\mathrm{pH}$ tolerance than larger species, probably due to a better regulation of their internal $\mathrm{pH}$ as they have a larger surface:volume ratio (Lundholm et al. 2004). For dinoflagellates, the results indicate that a similar semi-logarithmic relationship exists between $\mathrm{pH}$ tolerance and size (Fig. 5). The species that are able to tol-

Table 5. List of $\mathrm{pH}$ tolerances for growth for dinoflagellates based on the literature. Data are exclusively from studies in which growth was not considered as being nutrient limited. Asterisks refer to heterotrophic dinoflagellates. 1: Schmidt \& Hansen (2001); 2: Humphrey (1975); 3: Lee et al. (2003); 4: Hansen (2002); 5: Lundholm et al. (2005); 6: Møgelhøj et al. (2006); 7: Barker (1935); 8: Pedersen \& Hansen (2003b)

\begin{tabular}{|c|c|c|c|c|}
\hline Species & $\mathrm{pH}$ limit & Type of experiment & Source & Cell vol. $\left(\mu \mathrm{m}^{3}\right)$ \\
\hline Alexandrium ostenfeldii & 8.9 & $\mathrm{pH}$ drift & 1 & 17000 \\
\hline Alexandrium tamarense & 8.9 & $\mathrm{pH}$ drift & 1 & 17160 \\
\hline Amphidinium carterae & $>10.1$ & Non-constant $\mathrm{pH}$ & 2 & $650^{\mathrm{a}}$ \\
\hline Amphidinium sp. & $>9.5$ & Constant $\mathrm{pH}$ & 3 & $350^{\mathrm{a}}$ \\
\hline Ceratium lineatum & $8.8,8.8$ & $\mathrm{pH}$ drift, constant $\mathrm{pH}$ & 1,4 & 8100 \\
\hline Gymnodinium mikimotoi & 9.0 & pH drift & 1 & 5200 \\
\hline Gymnodinium splendens & $>8.9$ & Non-constant $\mathrm{pH}$ & 2 & $50000^{\mathrm{a}}$ \\
\hline Gyrodinium dominans* & 9.35 & Constant $\mathrm{pH}$ & 8 & $10400^{\mathrm{b}}$ \\
\hline Heterocapsa triquetra & $9.4,9.4,9.5,9.8$ & $2 \times \mathrm{pH}$ drift, constant $\mathrm{pH}, \mathrm{pH}$ drift & $1,5,4,6$ & 2050 \\
\hline Oxyrrhis marina* & $>9.9$ & Constant $\mathrm{pH}$ & 8 & $4600^{\mathrm{c}}$ \\
\hline Peridinium sp. & $\sim 9.5$ & Non-constant $\mathrm{pH}$ & 7 & $3000^{\mathrm{a}}$ \\
\hline Prorocentrum gracile & $\sim 9.5$ & Non-constant $\mathrm{pH}$ & 7 & $1900^{\mathrm{a}}$ \\
\hline Prorocentrum micans & $9.9,9.9, \sim 9.5$ & $2 \times \mathrm{pH}$ drift, non-constant $\mathrm{pH}$ & $1,6,7$ & 10000 \\
\hline Prorocentrum minimum & $9.6,9.6,9.9$ & Constant $\mathrm{pH}, 2 \times \mathrm{pH}$ drift & $4,1,6$ & 1040 \\
\hline
\end{tabular}




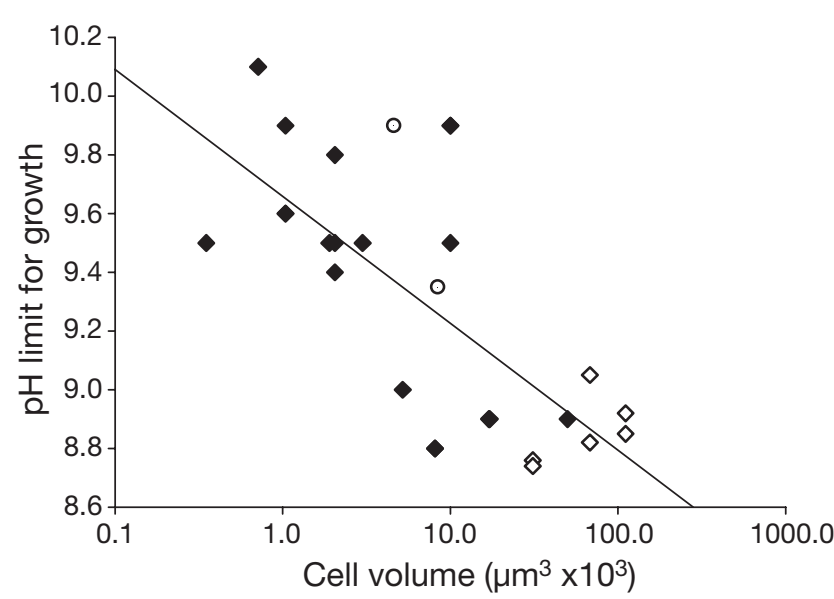

Fig. 5. Relationship between cell volume and $\mathrm{pH}$ limits for growth for dinoflagellates. Open data points represent results from present study; filled data points refer to Table 5 (dotted circles refer to heterotrophic dinoflagellates). Both $\mathrm{pH}$ drift and constant $\mathrm{pH}$ experiments have been included. Linear regression for all data points, $\mathrm{r}^{2}=0.51$

erate high $\mathrm{pH}$ are all small. To confirm this trend more studies on the upper $\mathrm{pH}$ tolerance of large dinoflagellates are needed, however.

All the dinoflagellates in Table 5 are neritic and/or oceanic species, but since none of the species are exclusively neritic in their distribution, no conclusions can be made on the $\mathrm{pH}$ tolerance of neritic versus oceanic species. Even though the upper $\mathrm{pH}$ limits for growth for dinoflagellates do not differ from $\mathrm{pH}$ limits for phytoplankton in general, a mesocosm experiment indicates that dinoflagellates tend to dominate when $\mathrm{pH}$ is high (Hinga 1992). It has been suggested that mixotrophic dinoflagellates may have an advantage during high $\mathrm{pH}$, due to phagotrophic carbon acquisition, since uptake of organic carbon has little impact on the charge balance of the cell (Hinga 1992). The $\mathrm{pH}$ limits for growth for dinoflagellates are measured for phototrophic carbon uptake and do not take the possible advantage of mixotrophy at high $\mathrm{pH}$ into consideration. Further studies are required to test this hypothesis.

\section{CONCLUSIONS}

The $\mathrm{pH}$ drift experiment was designed to mimic the coexisting $\mathrm{pH}$ rise and inorganic carbon depletion in nature during phytoplankton blooms, and thus the effects of high $\mathrm{pH}$ and low photosynthetically available DIC cannot be separated in these experiments. Our results illustrate that $\mathrm{pH}$ drift experiments in some cases give lower $\mathrm{pH}$ limits for growth than constant $\mathrm{pH}$ experiments; a likely explanation for the lower $\mathrm{pH}$ limit for growth is the combined pH/DIC limitation at high $\mathrm{pH}$ in the present $\mathrm{pH}$ drift experiments. Under natural conditions, high $\mathrm{pH}$ can be a limiting factor for the growth of Ceratium and many other dinoflagellate species with $\mathrm{pH}$ tolerances below or around 9, especially in coastal waters during summer. Low DIC, on the other hand, appears only to limit very large species such as C. furca and C. tripos at high $\mathrm{pH}$.

Acknowledgements. We thank C. Esplund and E. Granéli, University of Kalmar, for analysis of nutrients. This research was funded by the Danish Natural Research Council Project No. 21-03-0449 for P.J.H.

\section{LITERATURE CITED}

Badger MR (2003) The roles of carbonic anhydrases in photosynthetic $\mathrm{CO}_{2}$ concentrating mechanisms. Photosynth Res $77: 83-94$

Barker HA (1935) The culture and physiology of the marine dinoflagellates. Arch Mikrobiol 6:157-181

Bartual A, Gálvez JA (2002) Growth and biochemical composition of the diatom Phaeodactylum tricornutum at different $\mathrm{pH}$ and inorganic carbon levels under saturating and subsaturating light regimes. Bot Mar 45:491-501

Brussaard CPD, Gast GJ, van Duyl FC, Riegman R (1996) Impact of phytoplankton bloom magnitude on a pelagic microbial food web. Mar Ecol Prog Ser 144:211-221

Burkhardt S, Amoroso G, Riebesell U, Sültemeyer D (2001) $\mathrm{CO}_{2}$ and $\mathrm{HCO}_{3}{ }^{-}$uptake in diatoms acclimated to different $\mathrm{CO}_{2}$ concentrations. Limnol Oceanogr 46(6):1378-1391

Chen CY, Durbin EG (1994) Effects of pH on the growth and carbon uptake of marine phytoplankton. Mar Ecol Prog Ser 109:83-94

Clark DR, Flynn KJ (2000) The relationship between the dissolved inorganic carbon concentration and growth rate in marine phytoplankton. Proc R Soc Lond B 267: 953-959

Codispoti LA, Friederich GE, Iverson RL, Hood DW (1982) Temporal changes in the inorganic carbon system of the south-eastern Bering Sea during spring 1980. Nature 296: 242-245

Gaines G, Elbrächter M (1987) Heterotrophic nutrition. In: Taylor FJR (ed) The biology of dinoflagellates. Blackwell Scientific Publications, Oxford, p 224-268

Guillard RRL (1983) Culture of phytoplankton for feeding invertebrate animals. In: Berg CJ (ed) Culture of marine invertebrates. Hutchinson Ross Publishing, Stroudsberg, PA, p 123-128

Hansen G, Larsen J (1992) Dinoflagellater i danske farvande. In: Thomsen HA (ed) Plankton i de indre danske farvande. Havforskning fra Miljøstyrelsen No. 11. Miljøstyrelsen, Copenhagen

Hansen PJ (1992) Particle size selection, feeding rates and growth dynamics of marine heterotrophic dinoflagellates, with special emphasis on Gyrodinium spirale. Mar Biol 114:327-334

Hansen PJ (2002) Effect of high pH on the growth and survival of marine phytoplankton: implications for species succession. Aquat Microb Ecol 28:279-288

Hansen PJ, Lundholm N, Rost B (2007) Growth limitation in marine red-tide dinoflagellates: effects of $\mathrm{pH}$ versus inorganic carbon availability. Mar Ecol Prog Ser 334:63-71

Havskum H, Hansen PJ (2006) Net growth of the bloomforming dinoflagellate Heterocapsa triquetra and $\mathrm{pH}$ : why turbulence matters. Aquat Microb Ecol 42:55-62 
Hein M, Sand-Jensen K (1997) $\mathrm{CO}_{2}$ increases oceanic primary production. Nature 388:526-527

Hillebrand H, Dürselen C, Kirschtel D, Pollingher U, Zohary T (1999) Biovolume calculation for pelagic and benthic microalgae. J Phycol 35:403-424

Hinga KR (1992) Co-occurrence of dinoflagellate blooms and high $\mathrm{pH}$ in marine enclosures. Mar Ecol Prog Ser 86: 181-187

Hinga KR (2002) Effects of pH on coastal marine phytoplankton. Mar Ecol Prog Ser 238:281-300

Humphrey GF (1975) The photosynthesis: respiration ratio of some unicellular marine algae. J Exp Mar Biol Ecol 18: 111-119

Jansen S, Riser CW, Wassmann P, Bathmann U (2006) Copepod feeding behaviour and egg production during a dinoflagellate bloom in the North Sea. Harmful Algae 5: 102-112

Jensen BS (1994) Fire udvalgte Ceratium-arters biologi, økologi og udbredelse i danske farvande. MS thesis, University of Aarhus

Kempe S, Pegler K (1991) Sinks and sources of $\mathrm{CO}_{2}$ in coastal seas: the North Sea. Tellus 43B:224-235

Lee JJ, Shpigel M, Freeman S, Zmora O and others (2003) Physiological ecology and possible control strategy of a toxic marine dinoflagellate, Amphidinium sp., from the benthos of a mariculture pond. Aquaculture 217:351-371

Lindahl O, Hernroth L (1983) Phyto-zooplankton community in coastal waters of western Sweden-An ecosystem off balance? Mar Ecol Prog Ser 10:119-126

Lundholm N, Hansen PJ, Kotaki Y (2004) Effect of pH on growth and domoic acid production by potentially toxic diatoms of the genera Pseudo-nitzschia and Nizschia. Mar Ecol Prog Ser 273:1-15

Lundholm N, Hansen PJ, Kotaki Y (2005) Lack of allelopathic effects of the domoic acid-producing marine diatom Pseudo-nitzschia multiseries. Mar Ecol Prog Ser 288:21-33

Macedo MF, Duarte P, Mendes P, Ferreira JG (2001) Annual variation of environmental variables, phytoplankton species composition and photosynthetic parameters in a coastal lagoon. J Plankton Res 23(7):719-732

Mackereth FJH, Heron J, Talling JF (1978) Water analysis: some revised methods for limnologists. Scientific Publication No. 36, Freshwater Biological Association, Windermere

Millero FJ (1996) Chemical oceanography. CRC Press, Boca Raton, FL

Møgelhøj M, Hansen PJ, Henriksen P, Lundholm N (2006)

Editorial responsibility: Howard Browman (Associate Editorin-Chief), Storebø, Norway
High $\mathrm{pH}$ and not allelopathy may be responsible for negative effects of Nodularia spumigena on other algae. Aquat Microb Ecol 43:43-54

Pedersen MF, Hansen PJ (2003a) Effects of high pH on a natural marine planktonic community. Mar Ecol Prog Ser 260: 19-31

Pedersen MF, Hansen PJ (2003b) Effects of high pH on the growth and survival of six marine heterotrophic protists. Mar Ecol Prog Ser 260:33-41

Plath DC, Johnson KS, Pytkowicz RM (1980) The solubility of calcite-probably containing magnesium - in seawater. Mar Chem 10:9-29

Raven JA (1980) Nutrient transport in microalgae. Adv Microb Physiol 21:47-226

Raven JA (2003) Inorganic carbon concentrating mechanisms in relation to the biology of algae. Photosynth Res 77: 155-171

Riebesell U (2004) Effects of $\mathrm{CO}_{2}$ enrichment on marine phytoplankton. J Oceanogr 60:719-729

Rost B, Richter K, Riebesell U, Hansen PJ (2006) Inorganic carbon acquisition in red tide dinoflagellates. Plant Cell Environ 29:810-822

Schippers P, Lürling M, Scheffer M (2004) Increase of atmospheric $\mathrm{CO}_{2}$ promotes phytoplankton productivity. Ecol Lett 7:446-451

Schmidt LE, Hansen PJ (2001) Allelopathy in the prymnesiophyte Chrysochromulina polylepis: effect of cell concentration, growth phase and pH. Mar Ecol Prog Ser 216: $67-81$

Smetacek V (1981) The annual cycle of protozooplankton in the Kiel Bight. Mar Biol 63:1-11

Steidinger KA, Tangen K (1997) Dinoflagellates. In: Tomas CR (ed) Identifying marine phytoplankton. Academic Press, San Diego, CA, p 387-584

Taraldsvik M, Myklestad SM (2000) The effect of pH on growth rate, biochemical composition and extracellular carbohydrate production of the marine diatom Skeletonema costatum. Eur J Phycol 35:189-194

Thomas H, Schneider B (1999) The seasonal cycle of carbon dioxide in Baltic Sea surface waters. J Mar Syst 22:53-67

Utermöhl H (1958) Zur Vervollkommnung der quantitativen Phytoplankton-Methodik. Mitt Int Ver Theor Angew Limnol 9:1-38

Valderrama JC (1995) Methods of nutrient analysis. In: Hallegraeff GM, Anderson DM, Cembella AD (eds) Manual of harmful marine microalgae. IOC manuals and guides, Vol 33. UNESCO, Paris, p 251-268

Submitted: December 19, 2006; Accepted: July 7, 2007

Proofs received from author(s): November 6, 2007 